\title{
Efficiency of Financial Markets in Transition: The Case of Macroeconomic Releases
}

\author{
Richard Podpiera ${ }^{1}$ \\ July 2000
}

\begin{abstract}
This paper contributes to the discussion on the efficiency of newly emerged financial markets in transition economies. We use data on one of the most developed financial markets in transition, the Czech Republic, to investigate financial market efficiency by examining the reaction to macroeconomic releases. Direct measure of market expectations, that is, survey data, is used to form a proxy for market expectations. The reactions of interest rates, bond yields, exchange rates, and the stock market index are explored. We found that, despite the fact that the survey data appear to reasonably approximate rational expectations, the Czech market lacks basic efficiency properties. It reacts to the expected part of the news announcement, and the adjustment is stretched over a period of several days. In the case of CPI, we found evidence suggesting that the efficiency of the market improves over time.
\end{abstract}

Abstrakt: Tento článek přispívá $\mathrm{k}$ diskusi o efektivnosti nových kapitálových trhů $\mathrm{v}$ tranzitivních ekonomikách. Za použití údajů o jednom $\mathrm{z}$ nejrozvinutějších finančních trhů v této skupině zemí, v České republice, zkoumáme stupeň efektivnosti finančního trhu podle reakce na oznámení nových makroekonomických dat. Očekávání trhu měříme přímo, pracujeme s výsledky průzkumu mezi účastníky trhu. Zaměřili jsme se na reakci úrokových sazeb, výnosu dluhopisu, směnného kurzu koruny a akciového indexu. I když očekávání je podle našich výsledků přibližně racionální, český finanční trh se zdá být výrazně neefektivní nebot při oznámení nových údajů reaguje i na očekávanou část publikovaných čísel a navíc úplné přizpůsobení trhu trvalo několik dní. Testy strukturálních změn naznačují, že v prrípadě spotřebitelských cen se efektivnost trhu zlepšuje.

Keywords: market efficiency, emerging markets, market response, macroeconomic release

\author{
JEL Classification: G14
}

\footnotetext{
${ }^{1}$ CERGE-EI and Atlantik finanční trhy. CERGE-EI is a joint workplace of Charles University and the Academy of Sciences of the Czech Republic, Prague. Correspondence to: CERGE-EI, P.O. Box 882, Politických vězňů 7, 111 21, Prague, Czech Republic. E-mail: Richard.Podpiera@cerge.cuni.cz.

I would like to thank Jan Hanousek, Randall Filer, Jan Kmenta, Viktor Kotlán and Jan Schiesser for helpful comments. The usual disclaimer applies. I acknowledge the support of ACE grant No. 97-8118R.
} 


\section{Introduction}

Financial markets in transition economies have developed significantly over the past decade. Some of them developed to such a degree that it is now possible to inquire into the efficiency of their reaction to new information. One of the basic characteristics of an efficient market is that prices quickly incorporate new information. The semi-strong version of the efficient market hypothesis states that prices of financial instruments should incorporate all publicly available information. It is widely acknowledged that macroeconomic information is relevant for financial markets, and a number of studies, some cited below, have found that developed financial markets react quickly to releases of macroeconomic information.

In this paper we investigate financial market efficiency in the case of one of the most advanced countries in transition, the Czech Republic, from the point of view of the market's reaction to macroeconomic releases. While great attention has been devoted to testing (mainly equity) market efficiency with respect to company-specific news such as dividend changes, earning announcements or stock splits, we believe it is more appropriate to use macroeconomic data and money markets for testing market efficiency in the transitioneconomy setting. There are two reasons for this. Firstly, procedures for the release of company-specific data are not settled in emerging markets and there is, therefore, a substantial danger of leakage. Secondly, equity markets tend to be generally less developed in transition economies than in foreign exchange and money markets. Indeed, we chose to study the Czech Republic mainly because of its liberalized foreign exchange market and developed money market.

We ask the basic questions of whether the financial market reacts to new macroeconomic information and to what extent this reaction is efficient. If the market is efficient, prices of financial instruments should adjust to new information immediately after such information is announced. Lagged adjustment, on the other hand, suggests market 
inefficiency. Since public information should have already been incorporated into the prices, the market should not react to the expected part of announcements. The market should, instead, respond only to genuinely new information, that is, any surprises in the released figures. We explore the reaction of the Czech crown exchange rate, inter-bank interest rates, swap and forward rates, the equity market index, and a government bond yield to monthly releases of inflation rates (both consumer price index and industrial producer prices), industrial production and foreign trade balances.

Clearly, in order to test for market reaction, we need to obtain an estimate of market expectations. We use a direct method of measuring market expectations by relying on survey data, taking the Reuters' poll of analysts as an approximation of the market's expectations. This poll is the most representative survey available and is broadly accessible to market participants. We also pretest for rationality (unbiasedness) of the forecasts before using them as a proxy for market expectations.

Two approaches to testing market reaction to news releases exist in the literature. The key distinction between them is the way in which market expectations are measured. The first approach uses a direct measure of market expectations, that is, survey data. Aggarwal et al. (1995) provide a short survey of several studies that use Money Market Services forecasts as the measure of market expectations. The second approach uses forecasts embedded in the market prices of financial instruments. This method, however, suffers from a conceptual problem in that it tests jointly for market efficiency and the validity of the model used to extract expectations from prices. Under some circumstances this approach might be justified. Amihud (1996) for example uses CPI-linked bonds to extract market expectations from financial markets. Nevertheless, even in such a clear-cut case, the issue of unobserved risks might complicate estimation. The fact that emerging markets are generally less developed and less liquid also makes the extraction of market expectations from prices less attractive relative 
to the developed-market setting. The less developed a market is, the lower the information value of its prices. Given these problems, we believe that the first approach is considerably more suitable for countries in transition than the second one.

A number of empirical investigations of market reactions to macroeconomic announcements have been performed for developed financial markets. These have concentrated on the impact of money stock announcements and central bank interest rate changes on the equity, money, and bond markets. Instead of providing a complete survey of this literature, we cite only selected relevant studies. Urich and Wachtel (1981) investigated market responses to weekly money supply announcements. More recently, Sadeghi (1992) investigated Australian data for stock market response to unexpected macroeconomic news, but his approach requires considerably more data than is available in the Czech Republic. A short study similar to ours was conducted by Smirlock (1986), who investigated the impact of inflation announcements on the long-term bond market. Overall, findings confirm that the markets are efficient, reacting only to the surprise component of the news announcement.

The most recent studies that deal with market reaction to news releases concentrate on high frequency data; see for instance Almeidal et al. (1998) for the treatment of the effects of macroeconomic news on high frequency exchange rate (DEM/USD) data. Ederinggton and Lee (1995) explore the short run dynamics of price adjustments in interest rate and foreign exchange markets to new information. Fleming and Remolona (1999) look into the term structure of information announcement effects in a high frequency data setting. The general conclusion of these studies is that the price adjustment is very rapid.

A separate stream of literature exists that develops theoretical models for the impact of information on prices in financial markets. Smirlock (1986) reviews the expected inflation and policy anticipation hypotheses for the impact of inflation announcements on interest rates. For a theoretical model of money supply announcements in an open economy framework, see 
Deaves (1990). Hoffman and Schlagenhauf (1985) deal with the impact of news on the foreign exchange market and alternative theories of exchange rate determination.

These studies, along with those not cited, deal with market efficiency with respect to reaction to news in developed markets. To our knowledge, no study so far has dealt with market reaction to new information in a transition economy. Lack of previous research is most likely attributable to the unsettled nature of the markets and, perhaps more importantly, to a lack of data. Thus, one key contribution of the current paper lies in its focus on an economy in transition.

Our findings differ substantially from those found in developed markets. While the developed market literature finds market reactions that are generally efficient, our findings show that that the reaction of the Czech financial market is far from efficient. Although the market reacts to announcements, its reaction is by no means immediate. Results suggest that the market needs several days to adjust to new information, with announcements retaining power to explain daily changes several days after the release. Moreover, the market appears to react not only to surprises in the releases, but also to the expected part of the release. In the case of CPI, testing for structural breaks suggests that this inefficiency diminishes over time. Inter-bank interest rates and swap and forward rates appear to be the most responsive to macroeconomic releases. Foreign exchange rates and bond yields respond less and there was little significant reaction of the stock market index. In terms of the number of financial variables responding to the release, the CPI appears to be the most important out of the four types of information releases studied.

In the next section, we provide a very brief description of the economic environment during the time period under study. Then, Section 3 presents a description of the economic and financial data, while Section 4 provides a short evaluation of the survey data. The 
methodology for efficiency testing is discussed in Section 5, while results can be found in Section 6. Section 7 concludes.

\section{Economic Environment}

Data availability limits us to roughly two and a half years from November 1997 to April 2000. Overall, this was a time of deepening economic recession in the Czech Republic. After exhibiting a slowing growth rate in 1997, the GDP started to decrease in 1998, with the decline deepening through the first quarter of 1999. Only in the second quarter of 1999 did the recession end and the GDP grew slightly in the rest of 1999. Industrial production was growing rapidly in late 1997 and during the first half of 1998, but then gradually slowed and started to decline in late 1998. The decline persisted through almost the whole year of 1999, and only in late 1999 and at the beginning of 2000 were positive industrial production figures seen.

The recession was accompanied by a sharp slowdown in inflation, with the year-onyear inflation rate falling from over 13\% in early 1998 to just over $1 \%$ in the second half of 1999. This decline was caused by several factors including declining domestic demand, low world commodity (especially oil) prices, little increase in regulated prices and a strong crown. ${ }^{2}$ The economic slowdown helped narrow the foreign trade deficit (which was $8.3 \%$ of GDP in 1997) to 4.3\% of GDP in 1998, with further narrowing in 1999.

Several months before our period started, in May 1997, the Czech Republic went through a currency crisis. Before the crisis began, the crown was fixed against a basket consisting of $65 \%$ DEM and $35 \%$ USD, with a fluctuation band of $\pm 7.5 \%$. Wide trade and current account deficits, combined with political instability, inspired an attack on the Czech

\footnotetext{
${ }^{2}$ The Czech currency, as described below, was strong due to high nominal and real interest rates in the first part of the period covered and strong inflow of foreign direct investments in the later part. It thus appears that at least in the later part the causality went from the strong crown to lower prices rather than vice versa.
} 
currency. The Czech National Bank tried to defend the crown and increased interest rates significantly. After several days, however, the crown was floated and since then it has had no pre-set fluctuation band.

Interest rates were, therefore, relatively high in the first part of our period (late 1997) since the Czech National Bank only gradually lowered interest rates, which, nevertheless, remained above the pre-crisis level. Only in mid-1998 did the central bank start to cut its interest rates significantly. These interest rate cuts, though rather frequent and sometimes large, barely managed to keep pace with the sharply declining inflation rate.

The crown rebounded after its May 1997 depreciation. In the second half of 1997 and the first half of 1998, high nominal and arguably also real interest rates attracted short term capital, which supported the crown. ${ }^{3}$ Later, in the second half of 1998 and mainly in 1999, it was the inflow of foreign direct investments that caused the crown to be relatively strong. Although the Czech currency floats rather freely, the central bank does intervene in the foreign exchange market from time to time. ${ }^{4}$ As for the other economic indicators, no clear trend was seen in the Czech stock market over the period we follow. Bond prices, naturally, reacted to falling inflation and interest rates and increased significantly.

\footnotetext{
${ }^{3}$ Whether besides nominal interest rates also the real ones were high is arguable because it is difficult to quantify inflation expectations. Our view is that the decline of inflation was, at least partially, expected and thus also real interest rates were unusually high.

${ }^{4}$ The most recent example of such intervention is that of March 30, 2000, when the central bank intervened against the crown. It said that the Czech currency was too strong relative to the euro, which threatened the recovery of the economy. The intervention led to crown depreciation from approximately $35.50 \mathrm{CZK} / \mathrm{EUR}$ to $36.30 \mathrm{CZK} / \mathrm{EUR}$ and the crown stayed below the $36 \mathrm{CZK} / \mathrm{EUR}$ mark for more than a month. The bank, however, did not release any specific target rates for the crown.
} 


\section{Data Description}

Probably the most suitable proxy for the consensus market expectations in the Czech Republic is the Reuters poll of analysts and economists. This poll is conducted at the beginning of each month and asks for predictions of the main macroeconomic figures due for release during the following month. Typically, some 20 analysts and economists submit their estimates. The belief that this survey is the most suitable is based on two facts. First, this poll is the most representative one available. Other agencies also question analysts on their expectations, but their polls are generally less representative and formal. Second, and even more important, the Reuters poll is regularly released with a time lead before the publication of the figures-in fact, immediately as the estimates are collected. ${ }^{5}$ This strengthens its position as a proxy for market expectations - those market participants who do not have their own estimates will tend to form their expectations close to the consensus and compare the actual result with the poll's prediction.

The Reuters poll data are available from October 1997 to March 2000. In fact, we would not be able to use earlier data even if they were available, since they would be affected by the monetary turbulence of May 1997. It appears to be a safe assumption that by five months after the crisis markets returned to normal functioning and this is, in fact, supported by empirical evidence. Firstly, the bid-ask spread on the inter-bank money market, which among other issues reflects the uncertainty of market makers, averaged 20-30 basis points (for all maturities) in the months preceding the crises. In May, the average spread increased to as much as 16 percentage points for the two-week rate and over 3 percentage points for the

\footnotetext{
${ }^{5}$ The second most widely followed news agency, Bloomberg, also conducts its own surveys and releases them prior to the publication of the macroeconomic figures. However, the results of these surveys are not included as a special news item (as is the case at Reuters). The Reuters survey is released two working days before the publication of the first figures in each month (CPI). In other words, the Reuters poll results are published on day $\mathrm{T}-2$ in the afternoon, with the day $\mathrm{T}$ being the release day of the CPI figures.
} 
longest (one-year) rate. By September, then, the spread returned to a level comparable with its pre-crisis position. ${ }^{6}$ Secondly, the volatility of interest rates, as measured by the standard deviation of interest rates, developed very similarly. ${ }^{7}$ We thus have 30 observations for the expected consumer price index, industrial producer prices, industrial production and the trade deficit. The poll reports the average, median, minimum and maximum forecasts. Unemployment rate was added to the poll only recently, so there is not enough data.

For financial variables, we used daily data, despite the fact that developed-market studies using high frequency data suggest that adjustment may be very rapid. In fact, we started with daily data with the eventual aim to continue with more frequent data. However, given that we found inefficient market reactions at the daily level we did not need to continue with more frequent data.

For exchange rates, we had a choice between currency fixing reported by the Czech National Bank and the market rates reported by Reuters or Bloomberg. The exchange rate of the Czech crown is fixed by the CNB at 11:30 a.m. on each day. While there are 2.5 hours between the time of the macroeconomic data announcement $(9$ a.m.) and the fixing (11:30 a.m.), the market might need longer to adjust to the information. In our data, this would shift the reaction to the following day $(\mathrm{T}+1)$, even though it actually happened on the day of the announcement (T). Also, the central bank has discretion when fixing the currency, as opposed to direct averaging of market makers' quotes. ${ }^{8}$ Market quotes reported by Reuters and Bloomberg come from the market directly, and using closing prices allows the full day of

\footnotetext{
${ }^{6}$ At the end of 1997, turbulence in foreign markets (Russia) increased the spread again, but this increase was much smaller than that induced by the May 1997 crisis.

${ }^{7}$ In the months prior to the May 1997 crisis, the average daily standard deviation ranged between 1 and 15 basis points. During the crisis it peaked between 4 and 33 percentage points (depending on maturity). By September, the standard deviations returned to the pre-crisis level.

${ }^{8}$ Even though the central bank argues that its only aim is to mirror the development of the market, it is possible that it uses the fixing as a policy or signaling tool and thus introduces some bias into the data. Our preference is to use the data observed directly on the market.
} 
trading for incorporating the new information. Given these facts, we have chosen to use the market data.

For inter-bank interest rates, the history of market quotes is not available. On the other hand, PRague Inter-Bank Offer Rate (PRIBOR), which is published by the central bank, reflects directly the quotes of commercial banks and the CNB has no discretion relative to its level. In this sense, PRIBOR fixing data are more appropriate for our purpose than the currency fixing. PRIBOR is released at 11:00 a.m. each day; we use PRIBOR rates with maturities ranging from 1 week to 1 year. We have also chosen to use one, three, five, seven and ten year swap rates, as well as forward rates $3 * 6,6 * 9,9 * 12,3 * 9,6 * 12 .^{9}$ The swap and forward rates were obtained from Bloomberg, which collects them from market participants.

The PX-50 is the most closely followed Czech stock market index. It is broadly representative in that it includes virtually all stocks that have significant liquidity. To represent the bond market, we examined the yield to maturity on the government bond maturing in August 2002. ${ }^{10}$ Bond data were obtained from Bloomberg, which compiles them from the market makers.

The Czech Statistical Office collected and released the macroeconomic data. The schedule for announcements is set long in advance and is available to all market participants. Releases are made at 9:00 a.m. through the Internet and other electronic media and are embargoed at Reuters and Bloomberg until 9:00 a.m. Thus new information is released simultaneously to all market participants. The statistical office is generally strict in its adherence to secrecy rules. Although there were some alleged leakages during the time period

\footnotetext{
${ }^{9}$ The notation $3 * 9$, for instance, denotes a current contract on a six month rate starting three months from today.

${ }^{10}$ Government bond $12.2 \% 08 / 02$.
} 
under study, we do not believe this could be an important factor since none of them concerned the data we examine. ${ }^{11}$

\section{Analysis of the Poll Data}

At first, we review the basic statistical characteristics of the poll in terms of the precision of its forecasts and the existence of systematic biases. The consumer and industrial producer price index forecasts appear to be unbiased, with an average error of only 4 and 5 basis points, respectively. Also, the releases fell into the forecasted range in a substantial majority ( $80 \%$ for CPI and $73 \%$ for PPI) of cases. Industrial production exhibits somewhat poorer results in terms of the average mistake. However, only 5 times ( $17 \%$ of the cases) was the surprise so large that the actual figure did not fall into the forecasted range.

Table 1: Basic Characteristics of the Reuters Poll of Economic Releases

\begin{tabular}{|c|c|c|c|c|}
\hline & $\begin{array}{c}\text { Consumer } \\
\text { price index } \\
(\mathrm{m} / \mathrm{m}, \%)\end{array}$ & $\begin{array}{l}\text { Industrial PPI } \\
(\mathrm{m} / \mathrm{m}, \%)\end{array}$ & $\begin{array}{l}\text { Industrial } \\
\text { production } \\
\text { (\% change) }\end{array}$ & $\begin{array}{c}\text { Foreign } \\
\text { trade deficit } \\
\text { (bn } \mathrm{CZK} \text { ) }\end{array}$ \\
\hline Average of (mean) expectations & 0.45 & 0.29 & 0.80 & 7.09 \\
\hline Average of actual figures & 0.41 & 0.24 & 0.59 & 7.13 \\
\hline Difference $=$ average error ${ }^{a}$ & $-0.04(-9 \%)$ & $-0.05(-17 \%)$ & $-0.21(-26 \%)$ & $0.04(1 \%)$ \\
\hline Average minimum & 0.11 & 0.02 & -2.40 & 3.87 \\
\hline Average maximum & 0.75 & 0.59 & 4.01 & 10.49 \\
\hline Number of releases out of the range ${ }^{b}$ & $6(20 \%)$ & $8(27 \%)$ & $5(17 \%)$ & $12(40 \%)$ \\
\hline Total number of releases & 30 & 30 & 29 & 30 \\
\hline
\end{tabular}

Source: Reuters, Czech Statistical Office, own calculation. ${ }^{a}$ Figures in parentheses are percentages of average expectations. ${ }^{b}$ Figures in parentheses are percentages of the total number of releases. Note: One data point was missing in case of industrial production.

A high volatility of the trade deficit caused the actual outcomes to be frequently out of the forecasted range. On average, though, the forecast errors cancelled out, since the average

\footnotetext{
${ }^{11}$ In fact, during the 1997-1999 period, there were only two reported cases of information leakage prior to the release date. Both cases concerned GDP figures which we do not use here. In the first one, the 4Q 1998 GDP figures were given to a daily newspaper one day before the official release date. In the second case, the 3Q 1999 data was sent out accidentally by e-mail to a group of ten journalists and analysts.
} 
mistake amounted only to $1 \%$ of the average expected outcome. Overall, the basic statistics suggest that the analysts' forecasts do not exhibit any serious systematic mistakes. ${ }^{12}$

In the above calculation of average errors the positive and negative forecast errors virtually cancel out, which is required from an unbiased forecast. In terms of actual precision of the forecasts, the average absolute value error would be a more suitable indicator. Then, the average mistake would be close to 20 basis points for CPI (around $40 \%$ of average expectations). Trade deficit and industrial production exhibit a similar level of the ratio of average (absolute value) error to average expectations. The forecasts thus do not appear to be very precise, but given the unsettled nature of the Czech economy-still a transition one with many systematic changes going on-one can rate their precision as satisfactory. ${ }^{13}$

In addition, we have tested the rationality of the survey forecasts in a more formal way. In order for the forecast to be considered rational, it must be, first of all, unbiased, since under rational expectations, economic agents do not make systematic errors. In contrast, autocorrelation of forecast errors would suggest adaptive rather than rational expectations. Following several previous studies on forecast rationality, the most recent of which is Aggarwal et al. (1995), we used the following model.

$$
Y_{t}=\alpha_{0}+\alpha_{1} Y_{t}^{e}+\varepsilon_{t}
$$

In this setting, in order for the forecasts to be rational, we require $\alpha_{0}=0, \alpha_{1}=1$ and $\mathrm{E}\left(\varepsilon_{t}\right)=0$. The disturbance $\varepsilon_{t}$ must be uncorrelated with the expected value $Y_{t}$ and must not exhibit any serial correlation. In the ideal case, one should test for stationarity and cointegration of the time series in question. On the other hand, we do not have enough data to

\footnotetext{
12 The difference between the actual and expected variables is not statistically significant in any of the cases.

${ }^{13}$ For comparable statistics concerning the Money Market Services surveys in the U.S. see Aggarwal et al. (1995). There, the difference between the mean expected and actual figures is narrower than in our case, but the variance of the actual figures is considerably smaller as well.
} 
seriously conduct such a test. The potential presence of nonstationarity and a unit root in the data, however, biases the coefficient $\alpha_{1}$ toward zero and toward rejection of the rationality hypothesis. Thus, we err on the conservative side. In fact, as shown below, this is not a major problem here, since it appears we are quite close to rationality.

Table 2: Testing the Rationality of Survey Forecasts

\begin{tabular}{|l|c|c|c|c|c|c|c|}
\hline & $\begin{array}{c}\alpha_{0} \\
(\text { coefficient })\end{array}$ & $\begin{array}{c}\alpha_{0}(\mathrm{t}- \\
\text { statistics })\end{array}$ & $\begin{array}{c}\alpha_{1} \\
\text { (coefficient) }\end{array}$ & $\begin{array}{c}\alpha_{1}(\mathrm{t}- \\
\text { statistics })\end{array}$ & $\begin{array}{c}\alpha_{1}(5 \% \\
\text { confidence } \\
\text { interval) }\end{array}$ & $\mathrm{N}$ & $\mathrm{R}$-sq. \\
\hline CPI & $-0.18^{* *}$ & -3.01 & $1.30^{* *}$ & 6.82 & $(0.9,1.7)$ & 30 & 0.92 \\
\hline PPI & 0.03 & 0.26 & $0.74^{*}$ & 1.94 & $(0.0,1.5)$ & 30 & 0.28 \\
\hline Industry & -0.33 & -0.87 & $1.15^{* *}$ & 14.76 & $(1.0,1.3)$ & 29 & 0.90 \\
\hline Trade & -0.52 & -0.42 & $1.08^{* *}$ & 6.11 & $(0.7,1.4)$ & 30 & 0.50 \\
\hline
\end{tabular}

Source: Own calculation. *denotes coefficients significantly different from zero at the $10 \%$ level, while **denotes the 5\% significance level. We have used the White heteroskedasticity-constistent estimator for standard errors since the LM test indicated the presence of changing variance.

The estimates of the simple regression model are depicted in the table above. All the coefficients $\alpha_{1}$ are significant and generally quite close to 1 . In fact, we were unable to reject the hypothesis that the coefficient $\alpha_{1}$ equals 1 in any of the four cases at the $5 \%$ significance level. ${ }^{14}$ With the exception of CPI, all constant terms are insignificant. Analysis of residuals, using the Q statistics, suggests that the disturbances are not plagued by autocorrelation. Our overall conclusion is that the survey data come reasonably close to exhibiting rational expectations.

\footnotetext{
${ }^{14}$ At the $10 \%$ significance level this hypothesis could be rejected only in the case of industrial production.
} 


\section{Methodology of Efficiency Testing}

We use the following simple econometric model in order to investigate market response to macroeconomic announcements.

$$
\Delta Y=\beta_{1} \text { Expected }+\beta_{2} \text { Surprise }+\beta_{3} \text { Repo }+\beta_{4} \text { Weekend }+\varepsilon
$$

where $\Delta \mathrm{Y}$ stands for daily change of a particular financial market variable-interest rate, exchange rate, yield to maturity of a government bond or stock market index. We have calculated daily changes - percentage changes for the exchange rates and stock market index and basis point changes for interest rates and the bond yield. The preceding day was always taken as the base. The variable Expected is defined as the average forecast from the Reuters poll, while Surprise is defined as the difference between announced and expected figures. The variable Repo stands for changes of the 2-week repurchase rate of the Czech National Bank, which is the key monetary tool the bank uses. ${ }^{15}$ As mentioned above, the central bank undertook a series of interest rate cuts that affected financial markets during the time period we focus on. One might argue that the rate cuts were expected and that it does not make much sense to include the actual rate changes as an explanatory variable. Our justification for including this variable is based on an earlier work. In Podpiera (2000), we have estimated a separate model for the repo rate cuts and found that interest rates reacted significantly after the cut was announced, that is, the cuts were largely not anticipated. ${ }^{16}$ Indeed, this variable was significant in the estimation. Variable Weekend is a dummy that captures the effect of a weekend between two trading days. It equals 1 if there was a weekend between the day of the

\footnotetext{
${ }^{15}$ See, for instance, the Inflation Report of the Czech National Bank, October 1999.

${ }^{16}$ The lack of market efficiency and the absence of anticipatory movements were most visible in case of the shortest rates (one week to one month). These rates did not move until the day of the announcement of the repo rate change and adjusted to a new level gradually in the following five days.
} 
announcement and the particular trading day, and 0 otherwise. In the estimation, this variable was significant in a number of instances.

One might argue for assuming that the error term has a constant variance since we focus on a relatively short time period. On the other hand, financial time series are known to be prone to changing variances. We therefore tested for heteroskedasticity in the regression models by using an LM test. Since this test uncovered heteroskedasticity in a few instances, we used White heterosedasticity-robust standard error estimates. Also, in several cases an adjustment for autocorrelation was needed. ${ }^{17}$

In terms of the presented model, we conclude that markets react to an announcement if at least one of the coefficients $\beta_{1}$ and $\beta_{2}$ is statistically significant for some daily changes. For our purposes, given the data limitations, we refer to a coefficient as significant if it is statistically significant at the $10 \%$ level. Market efficiency requires that the market reacts immediately, that is, the coefficients should be significant only for the first (and, possibly, for the fixing data, second) day. Moreover, an efficient market should react only to the surprise and thus we should not see any significant coefficients for the Expected variable.

We estimate the model for 5 working days before the announcement and 9 working days after the release. Looking also at the time period prior to the announcement should reveal the existence of any market adjustment to the expected part of the release. In fact, since the poll's results are usually published 2 working days before the first macroeconomic release of the month (consumer prices and sometimes also industrial production), there might be a lagged adjustment to the poll's results. Studies from developed markets suggest that the results of polls are themselves taken as relevant news by the market—see Aggarwal et al. (1995). Separately, in all the following tables and discussion, we denote the day when the new

\footnotetext{
${ }^{17}$ In these cases we used the AR1 procedure in TSP that employs a maximum likelihood method to obtain the estimates.
} 
macroeconomic data was released as day $\mathrm{T}$. In this notation, we consider days in the range from $\mathrm{T}-5$ to $\mathrm{T}+8$.

\section{Results}

\subsection{Consumer Price Index}

The expected impact of the consumer price index on interest rates and bond yields is straightforward, at least in the short term. Smirlock (1986) cites the two most plausible hypotheses regarding financial market reaction to inflation announcements. These have received the most attention in the empirical literature. The first is the expected inflation hypothesis $(\mathrm{EIH})$, which states that positive inflation surprises lead to an upward revision of inflation expectations, raising short-term interest rates. The second is the policy anticipation hypothesis $(\mathrm{PAH})$, which argues that higher than expected inflation makes agents in the financial market expect a tightening of monetary policy. Again, short term interest rates should increase. While their predictions for short-term interest rates are the same, the two hypotheses differ in their prediction for long term rates. Long term rates always increase with positive inflation surprise under the EIH, while the PAH is consistent with either an increase or a decrease of long-term interest rates. This is due to the fact that the action of the central bank lowers expected long-term inflation. Reaction of long term rates thus might help to discriminate between the two hypotheses. We are unable to do this with the Czech data due to limited number of announcements. However, what might help us explain our results is the fact that the different predictions of the two hypotheses with respect to the reaction of long interest rates suggest that the response of bond prices and other longer rates, like swaps, will be weaker than that of short rates. 
The expected reaction of the foreign exchange market to CPI announcements is not straightforward. Relatively higher domestic inflation should lead to depreciation of the currency, if we believe that at least a relative version of purchasing power parity is valid. On the other hand, in the short term, higher inflation might lead to appreciation of the currency, especially in the environment of frequent interest rate cuts by the central bank. Here, higher inflation implies lower expected interest rate cuts and thus a more attractive domestic currency. The impact of CPI announcements on the stock market is connected with the impact on interest rates-lower rates imply a lower discount factor and should lead to higher stock prices and vice versa.

We had to overcome two problems when estimating the model for consumer prices. Firstly, there is an outlier observation in January 1998, when large administrative changes increased the level of consumer prices by $4 \%$. We have accounted for this unusually large increase, which has different implications in terms of future inflation than an increase in the core inflation, by including a dummy variable, equal to 1 for the January 1998 announcement and 0 otherwise. Secondly, industrial production figures are sometimes released several days after consumer prices and sometimes on the same day. In fact, on average, industrial production figures were released with a lag of 1.2 days after consumer prices, with the lag ranging between 0 and 6 working days. Industrial production thus might be a relevant variable in the regression explaining daily changes after the consumer price release and its exclusion might bias the coefficients. We have attempted to include two variables (expected and surprise) for industrial production into the consumer price equation, but the coefficients were insignificant in the vast majority of cases and, more importantly, the consumer price coefficients did not change to any significant extent. Also, the correlations between expected values and surprises in industrial production and CPI are not large, at 0.36 and 0.31 , respectively. We have concluded that we can ignore the fact that industrial production figures 
are released soon after consumer prices and we have thus estimated two separate equations for consumer prices and industrial production.

Estimation of the model suggests that the consumer price index is important news for financial markets, since inter-bank interest rates, bond yields, and the koruna exchange rate appear to react to the CPI announcements. Since there is not enough space for presentation of the complete regression results, we present an overview table here and a rather narrow selection of more detailed results in the Appendix. The overview table provides an idea of when the market response occurs and what its direction is. In the case of CPI we report results starting with day $\mathrm{T}-1$, since the poll results are reported in the afternoon of day $\mathrm{T}-2$ and the market cannot react to them sooner than on day T-1. In the Appendix we aimed at selecting a representative sample of the results.

Table 3a: Overview of the Regression Results for CPI

\begin{tabular}{|c|c|c|c|c|c|c|c|c|c|c|c|c|c|c|c|c|c|c|c|c|c|c|c|c|}
\hline & \multicolumn{2}{|c|}{$\begin{array}{c}\text { PRIB } \\
1 \mathrm{~W}\end{array}$} & \multicolumn{2}{|c|}{$\begin{array}{c}\text { PRIB } \\
1 \mathrm{M}\end{array}$} & \multicolumn{2}{|c|}{$\begin{array}{c}\text { PRIB } \\
6 \mathrm{M}\end{array}$} & \multicolumn{2}{|c|}{$\begin{array}{c}\text { PRIB } \\
1 Y\end{array}$} & \multicolumn{2}{|c|}{$\begin{array}{l}\text { GOV } \\
\text { YLD }\end{array}$} & \multicolumn{2}{|c|}{$\begin{array}{c}\text { SWAP } \\
5 \mathrm{Y}\end{array}$} & \multicolumn{2}{|c|}{$\begin{array}{c}\text { SWAP } \\
10 Y\end{array}$} & \multicolumn{2}{|c|}{$\begin{array}{c}\text { FWD } \\
3 * 6\end{array}$} & \multicolumn{2}{|c|}{$\begin{array}{l}\text { FWD } \\
9 * 12\end{array}$} & \multicolumn{2}{|c|}{ USD } & \multicolumn{2}{|c|}{ DEM } & \multicolumn{2}{|c|}{ PX-50 } \\
\hline & Ex & $\mathrm{Sr}$ & Ex & $\mathrm{Sr}$ & Ex & $\mathrm{Sr}$ & Ex & $\mathrm{Sr}$ & Ex & $\mathrm{Sr}$ & Ex & Ex & $\mathrm{Sr}$ & $\mathrm{Sr}$ & Ex & $\mathrm{Sr}$ & Ex & $\mathrm{Sr}$ & Ex & $\mathrm{Sr}$ & Ex & $\mathrm{Sr}$ & Ex & $\mathrm{Sr}$ \\
\hline T-1 & & & & & & & & & & & + & & + & & & & & & + & & & & & \\
\hline $\mathbf{T}$ & & + & & ++ & & + & & ++ & & ++ & * & + & & + & & ++ & & ++ & & & & & & \\
\hline $\mathrm{T}+1$ & + & & + & & & & & & ++ & & ++ & & ++ & & & $*$ & ++ & & & & + & * & $* *$ & \\
\hline $\mathrm{T}+2$ & & & ++ & $*$ & & & & & & & & & & & & & & & & & & & & \\
\hline $\mathrm{T}+3$ & & & & & ++ & & ++ & & & & & & & & & & & & + & & & & & \\
\hline$\overline{T+4}$ & ++ & ** & ++ & $* *$ & ++ & & ++ & & & & + & & ++ & & ++ & & ++ & & ++ & * & ++ & & & \\
\hline $\mathrm{T}+5$ & & & $* *$ & + & * & + & & ++ & & & & & & & & & & & & & ** & & & + \\
\hline $\mathrm{T}+6$ & & & & & ** & + & $*$ & ++ & & + & & ++ & $* *$ & & $* *$ & & *** & & & $* *$ & & & ++ & \\
\hline $\mathrm{T}+7$ & & & & & $*$ & & & & & & & & & & & & & & & & & & ++ & \\
\hline $\mathrm{T}+8$ & & & & & & & & & & & & & & & & & & & & * & & & & \\
\hline
\end{tabular}

Note: Negative coefficients significant at the $10 \%(*)$ level and $5 \%(* *)$ level. Positive coefficients significant at the $10 \%(+)$ level and $5 \%(++)$ level. Ex = expected, $\mathrm{Sr}=$ surprise. We report results through day $\mathrm{T}-1$ because, in terms of this table, poll results are released in the afternoon of day T-2.

There are no large differences in the reaction of short (1 week to 1 month) and long (3 months to 1 year) PRIBOR rates. All the four rates depicted in the above table react to the surprise on the day of the release $(\mathrm{T})$. Then, a lagged reaction to the expected part of the release occurs. This reaction is stretched over a period of several days, with the last positive coefficient at the Expected variable being usually observed on day $\mathrm{T}+4$. In most instances, we find a negative coefficient during the following days, which suggests that there is an overreaction and subsequent correction. Market overreaction is usually considered to be a 
typical feature of an emerging market. It is worth noting that virtually all of the statistically significant coefficients during the first days have the expected sign — they are positive, that is, higher than expected inflation leads to an increase in interest rates. As for the magnitude of the coefficients, the significant coefficients tend to be larger for the surprise variable. This is not surprising, however, as the magnitude of the surprises is smaller relative to the expected value. On average, if we do not take into account the correction, a one percentage point inflation announcement increases the PRIBOR rates by some 20 basis points when it is expected and by almost 40 basis points when it is not expected. The correction lowers the average reaction to 15 and 23 basis points, respectively.

The government bond market, on the other hand, appears to be closer to efficient. It reacts to the surprise on the day of announcement (T) and to the expected part on the following day $(\mathrm{T}+1)$. Then, though, there is very little further reaction. The adjustment to the released information thus appears to be more rapid than in the case of the PRIBOR rates. Again, the response to the surprise part is greater in magnitude than to the expected part. Swaps also respond to the surprise on the day of the release $(\mathrm{T})$ and we observe a reaction to the expected component during the following days. On the other hand, only in the case of swaps we found significant coefficients on the day before the release (T-1), which might be explained by the reaction to the release of the poll (on the afternoon of day T-2). Forward rates react strongly to the surprise on day $\mathrm{T}$, with coefficients being close to 0.4 . Also in the case of swaps, we often see a significant reaction to the expected component on the following day $(\mathrm{T}+1)$ and a lagged adjustment can be observed.

To sum up, Czech interest rates generally increase with the announcement of higher inflation. They react to both the expected and surprise components of the announcement. Some rates react almost immediately after the release, but the adjustment takes several working days in some cases. Only rarely can we observe movements in anticipation of the 
announcements. We thus do not find evidence that the release of the poll's results themselves would be regarded as important information.

The foreign exchange market also reacts to inflation releases, but its response is less pronounced than that of interest rates. The exchange rate moves only to a limited extent in anticipation of the release. In case of DEM, a reaction is seen on the first day after the release $(\mathrm{T}+1)$ and then there is a delayed adjustment. While the significant coefficients associated with the expected part of the release are mostly positive, those several significant coefficients associated with the surprise are mostly negative. Positive coefficients imply depreciation of the Czech currency, while negative ones imply appreciation. One could only speculate what is behind this mixed result. One explanation, as outlined above, might be that the CPI release brought information not only on the development inflation, but also on the probability of another, in that time frequent, interest rates cut by the central bank.

In the case of the stock market index (PX-50), we found only one significant coefficient at the Expected variable (on day $\mathrm{T}+1$ ) that we were able to interpret. It is negative, which suggest that higher inflation implies lower stock prices. This would correspond to expectations, but low liquidity on the Czech market is a reason for caution when interpreting the results.

It is a natural question whether the market reaction was the same during the whole period under study or whether a structural break could be detected. We were constrained by a low number of data points, so we first used the Chow predictive test (essentially an F-test in which there are very few data points in the period after the assumed break date). This test, however, did not reveal any significant structural change in the most recent data. Then, we split the sample into two parts_ — one from the start (November 1997) until the end of 1998 and 
the other from the beginning of 1999 until the most recent data point (April 2000) ${ }^{18}$ _

estimated two models and tested for structural break (again, an F-test, that is, testing the

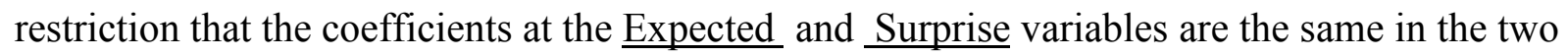

sub-periods). Estimation results are shown in the following tables.

Table 3b: Regression Results for CPI, November 1997 through December 1998

\begin{tabular}{|c|c|c|c|c|c|c|c|c|c|c|c|c|c|c|c|c|c|c|c|c|c|c|c|c|}
\hline & \multicolumn{2}{|c|}{$\begin{array}{c}\text { PRIB } \\
1 \mathrm{~W}\end{array}$} & \multicolumn{2}{|c|}{$\begin{array}{c}\text { PRIB } \\
1 \mathrm{M}\end{array}$} & \multicolumn{2}{|c|}{$\begin{array}{c}\text { PRIB } \\
6 \mathrm{M}\end{array}$} & \multicolumn{2}{|c|}{$\begin{array}{c}\text { PRIB } \\
1 Y\end{array}$} & \multicolumn{2}{|c|}{$\begin{array}{l}\text { GOV } \\
\text { YLD }\end{array}$} & \multicolumn{2}{|c|}{$\begin{array}{c}\text { SWAP } \\
5 \mathrm{Y}\end{array}$} & \multicolumn{2}{|c|}{$\begin{array}{c}\text { SWAP } \\
10 Y\end{array}$} & \multicolumn{2}{|c|}{$\begin{array}{c}\text { FWD } \\
3 * 6\end{array}$} & \multicolumn{2}{|c|}{$\begin{array}{l}\text { FWD } \\
9 * 12\end{array}$} & \multicolumn{2}{|c|}{ USD } & \multicolumn{2}{|c|}{ DEM } & \multicolumn{2}{|c|}{ PX-50 } \\
\hline & Ex & $\mathrm{Sr}$ & Ex & $\mathrm{Sr}$ & Ex & $\mathrm{Sr}$ & Ex & $\mathrm{Sr}$ & Ex & $\mathrm{Sr}$ & Ex & Ex & $\mathrm{Sr}$ & $\mathrm{Sr}$ & Ex & $\mathrm{Sr}$ & Ex & $\mathrm{Sr}$ & Ex & $\mathrm{Sr}$ & Ex & $\mathrm{Sr}$ & Ex & $\mathrm{Sr}$ \\
\hline T-1 & & & & & & & & & & .32 & .15 & & .13 & .24 & & .39 & & .50 & .80 & 1.5 & .76 & 1.7 & -.01 & \\
\hline $\mathbf{T}$ & & & .19 & & .07 & .43 & .06 & .55 & & .38 & & .56 & & .44 & & .62 & & .64 & & & & & -.01 & \\
\hline $\mathrm{T}+1$ & & & .04 & .15 & .10 & & .13 & .17 & .14 & & .21 & & .15 & & .13 & & .13 & & 1.3 & & 1.0 & & -.01 & .03 \\
\hline $\mathrm{T}+2$ & & & .02 & -.06 & & & & -.05 & & & .04 & & .06 & .11 & & & & & & & -.53 & -1.6 & & \\
\hline $\mathrm{T}+3$ & .09 & & .10 & .23 & .25 & .28 & .14 & .13 & & & & & -.08 & & & & & & & & .41 & & -.01 & \\
\hline $\mathrm{T}+4$ & .18 & & .16 & & .14 & & .12 & & & & & & & & .16 & & .13 & & .66 & -2.5 & & & & -.04 \\
\hline $\mathrm{T}+5$ & -.19 & & -.15 & & & & & & & & .06 & .22 & & .17 & & .22 & & .39 & & & & & & \\
\hline $\mathrm{T}+6$ & & & & & & & & & & & & .23 & -.08 & & & & -.13 & & & & & & & \\
\hline $\mathrm{T}+7$ & & & & & & & & & & & & & & & & & & & & & & & .01 & .04 \\
\hline $\mathrm{T}+8$ & & & & & & & & -.70 & & & & .39 & & & .04 & & & .32 & -2.0 & & & -1.9 & & \\
\hline
\end{tabular}

Note: In the table above we show the magnitudes of the coefficients which were significant at least at the $10 \%$ level. Ex = expected, Sr = surprise. The coefficients at USD and DEM need to be multiplied by $10^{-2}$.

Table 3c: Regression Results for CPI, January 1999 through April 2000

\begin{tabular}{|c|c|c|c|c|c|c|c|c|c|c|c|c|c|c|c|c|c|c|c|c|c|c|c|c|}
\hline & \multicolumn{2}{|c|}{$\begin{array}{c}\text { PRIB } \\
1 \mathrm{~W} \\
\end{array}$} & \multicolumn{2}{|c|}{$\begin{array}{c}\text { PRIB } \\
1 \mathrm{M} \\
\end{array}$} & \multicolumn{2}{|c|}{$\begin{array}{c}\text { PRIB } \\
6 \mathrm{M} \\
\end{array}$} & \multicolumn{2}{|c|}{$\begin{array}{c}\text { PRIB } \\
1 Y \\
\end{array}$} & \multicolumn{2}{|c|}{$\begin{array}{l}\text { GOV } \\
\text { YLD }\end{array}$} & \multicolumn{2}{|c|}{$\begin{array}{c}\text { SWAP } \\
5 \mathrm{Y}\end{array}$} & \multicolumn{2}{|c|}{$\begin{array}{c}\text { SWAP } \\
10 Y\end{array}$} & \multicolumn{2}{|c|}{$\begin{array}{c}\text { FWD } \\
3 * 6 \\
\end{array}$} & \multicolumn{2}{|c|}{$\begin{array}{l}\text { FWD } \\
9 * 12\end{array}$} & \multicolumn{2}{|c|}{ USD } & \multicolumn{2}{|c|}{ DEM } & \multicolumn{2}{|c|}{ PX-50 } \\
\hline & Ex & $\overline{\mathrm{Sr}}$ & $\overline{\text { Ex }}$ & $\overline{\mathrm{Sr}}$ & Ex & $\overline{\mathrm{Sr}}$ & $\overline{E x}$ & $\overline{\mathrm{Sr}}$ & $\overline{E x}$ & $\mathrm{Sr}$ & $\overline{E x}$ & $\overline{E x}$ & $\mathrm{Sr}$ & $\mathrm{Sr}$ & $\overline{\mathrm{Ex}}$ & $\overline{\mathrm{Sr}}$ & $\overline{\mathrm{Ex}}$ & $\overline{\mathrm{Sr}}$ & Ex & $\mathrm{Sr}$ & Ex & $\mathrm{Sr}$ & Ex & $\mathrm{Sr}$ \\
\hline T-1 & -.02 & & & & & & & & & & & & & & & & & & .43 & -1.3 & & & & \\
\hline $\mathbf{T}$ & & & & & & & & & & & & & & & & .24 & & .37 & & & & & & \\
\hline $\mathrm{T}+1$ & & & & & & & & & & & & & & & & & & & & & & -1.5 & & \\
\hline $\mathrm{T}+2$ & & & & & & & & & & & & & & & & & & & & 1.8 & & & & \\
\hline $\mathrm{T}+3$ & & & & & & & & & & & & & & & & & & & & & -.52 & & .03 & \\
\hline $\mathrm{T}+4$ & & & & .04 & & & & & & & & & & & & & & & & & & & & \\
\hline $\mathrm{T}+5$ & & .03 & & & & & & .06 & & & & & & & & & & & & & & -1.5 & & \\
\hline $\mathrm{T}+6$ & -.03 & & -.0 & .11 & & & & & & & & .15 & & & & & & & & -1.9 & & & .01 & \\
\hline $\mathrm{T}+7$ & -.01 & & -.0 & .12 & -.05 & .11 & -.06 & .08 & $\begin{array}{l}-06 \\
\end{array}$ & & & & & & & & & & -.3 & & & & & \\
\hline $\mathrm{T}+8$ & & .06 & -.0 & & -.05 & & -.04 & & & & & .12 & & & & & & & & & & & -.01 & \\
\hline
\end{tabular}

Note: In the table above we report the coefficients which were significant at least at the $10 \%$ level. Ex = expected, $\mathrm{Sr}=$ surprise. The coefficients at USD and DEM need to be multiplied by $10^{-2}$. The shading denotes the cases where we were able to reject the null hypothesis that the parameters are the same in the two subperiods.

The results suggest that the market response was different in the two sub-periods. In the first one, we see significant reaction of the interest rates to both the expected and surprise components of the releases. Moreover, the reaction to the expected part lasted for several days - a nice example of a prolonged reaction is the 1M PRIBOR, where we see six significant coefficients at the Expected variable in a row. The second part, however, does not show almost any reaction to the released figures. Formally, despite the low number of data

\footnotetext{
${ }^{18}$ This split, which is based on calendar time, resulted in an approximately even division of the data points. The two sub-samples include 14 and 16 data points, respectively.
} 
points, the results of the Chow test confirm the observation that the reaction was different in the two sub-periods - at least in the case of the PRIBOR rates. Here, in 13 of 40 possible cases we were able to reject the null hypothesis that the coefficients in the two time periods are the same (at least at the $10 \%$ significance level).

Overall, it appears that the market reacted strongly and inefficiently in late 1997 and 1998, while it responded very little in 1999 and early 2000. This finding can be interpreted as a shift toward efficiency, especially as we might have too few data points to find a more subtle and rapid market reaction in the later period. It is worth noting that the surprises in the two periods were roughly of the same magnitude. ${ }^{19}$ It might also be that the market attached different meaning to the CPI releases during the two periods. In the first period, year-on-year inflation decreased rapidly from above $13 \%$ to $3.5 \%$, while in the second period it stayed in the range of $1-4 \%$.

\subsection{Industrial Producer Price Index}

Industrial producer prices are generally followed much less closely than consumer prices. Industrial producer prices convey information about a narrower part of the overall price level in the economy. On the other hand, they might be viewed, to some extent, as a leading indicator for consumer prices. Thus, the expected market reaction is weaker, but similar, to that of CPI. Higher than expected inflation should, again, lead to higher interest rates and yields, with the impact on the koruna exchange rates being uncertain. Due to its leading nature, one would expect a more pronounced impact on longer interest rates.

\footnotetext{
${ }^{19}$ The average surprise was $-0.03 \%$ in the first period and $-0.05 \%$ in the second period. In absolute value, the average surprises amounted to $0.23 \%$ and $0.16 \%$, respectively.
} 
Table 4: Overview of the Regression Results for PPI

\begin{tabular}{|c|c|c|c|c|c|c|c|c|c|c|c|c|c|c|c|c|c|c|c|c|c|c|c|c|}
\hline & \multicolumn{2}{|c|}{$\begin{array}{c}\text { PRIB } \\
1 \mathrm{~W} \\
\end{array}$} & \multicolumn{2}{|c|}{$\begin{array}{c}\text { PRIB } \\
1 \mathrm{M} \\
\end{array}$} & \multicolumn{2}{|c|}{$\begin{array}{c}\text { PRIB } \\
6 \mathrm{M} \\
\end{array}$} & \multicolumn{2}{|c|}{$\begin{array}{c}\text { PRIB } \\
1 \mathrm{Y} \\
\end{array}$} & \multicolumn{2}{|c|}{$\begin{array}{l}\text { GOV } \\
\text { YLD } \\
\end{array}$} & \multicolumn{2}{|c|}{$\begin{array}{c}\text { SWAP } \\
5 \mathrm{Y}\end{array}$} & \multicolumn{2}{|c|}{$\begin{array}{c}\text { SWAP } \\
10 Y\end{array}$} & \multicolumn{2}{|c|}{$\begin{array}{c}\text { FWD } \\
3 * 6 \\
\end{array}$} & \multicolumn{2}{|c|}{$\begin{array}{l}\text { FWD } \\
9 * 12 \\
\end{array}$} & \multicolumn{2}{|c|}{ USD } & \multicolumn{2}{|c|}{ DEM } & \multicolumn{2}{|c|}{ PX-50 } \\
\hline & Ex & $\mathrm{Sr}$ & Ex & $\mathrm{Sr}$ & Ex & $\mathrm{Sr}$ & Ex & $\mathrm{Sr}$ & Ex & $\mathrm{Sr}$ & Ex & $\mathrm{Sr}$ & Ex & $\mathrm{Sr}$ & Ex & $\mathrm{Sr}$ & Ex & $\mathrm{Sr}$ & Ex & $\mathrm{Sr}$ & Ex & $\mathrm{Sr}$ & Ex & $\mathrm{Sr}$ \\
\hline T-4 & & ++ & & & & & & & & & & & & & & + & & & & & & & & \\
\hline T-3 & & & & & & & & & & & & & & & & & & & & $* *$ & & & & \\
\hline T-2 & + & & & + & & & & & & & & & & & & $*$ & & & & & & & & \\
\hline $\mathrm{T}-1$ & $*$ & & & & & & & & & & & & & & & ++ & & & & + & & & & \\
\hline $\mathbf{T}$ & & & & & & + & & + & & & & & & & & & & & & & $*$ & & & \\
\hline $\mathrm{T}+1$ & ++ & & ++ & & + & + & ++ & + & & & + & + & ++ & & + & + & + & ++ & + & & & & & \\
\hline $\mathrm{T}+2$ & + & & & & & & & + & + & & + & & & & & & & & & & & $*$ & & \\
\hline $\mathrm{T}+3$ & & & + & & & & & + & & + & & & & & & & & & $* *$ & & $* *$ & & & \\
\hline $\mathrm{T}+4$ & & & & & & & & & & & & & & & & ++ & & & & & & & & \\
\hline $\mathrm{T}+5$ & & & & & & & & & & & & + & & & & & & & & & & & & \\
\hline $\mathrm{T}+6$ & & & & & & + & & & & & & & & & & & & + & & & & & & \\
\hline $\mathrm{T}+7$ & & & & & & & & & & & & & $* *$ & & & & & & $*$ & & $* *$ & $* *$ & & \\
\hline $\mathrm{T}+8$ & & & & & & & & & & & & & & & & & & & & & & & & \\
\hline
\end{tabular}

Note: Negative coefficients significant at the 10\% (*) level and 5\% (**) level. Positive coefficients significant at the 10\% (+) level and 5\% (++) level. Ex = expected, $\mathrm{Sr}=$ surprise. We report results through day $T-4$ because, in terms of this table, poll results are released in the afternoon of day T-5.

Also here we present an overview of the regression results. The results basically confirm the expectations. The reaction of the market is weaker than its response to CPI. Interbank interest rates respond mostly on days $\mathrm{T}, \mathrm{T}+1$ and $\mathrm{T}+2$, all of them react to the expected part of the release and some also to the surprise. Only rarely was there a lagged response after day $\mathrm{T}+2$. A similar type of reaction was seen in case of swaps and forward rates. Overall, there was little movement prior to the publication of the figures. No strong reaction of the exchange rate was found. The significant coefficients in the case of DEM were all negative (implying that higher inflation depreciates the currency), but in case of USD we saw both negative and positive coefficients. We tested for structural change, but we found no strong evidence of a significant structural break in the market response. There were more significant coefficients in the first period, but the difference between the periods was much less visible than in the case of CPI. Also, we were able to reject the null hypothesis of the same coefficients only in several cases.

\subsection{Industrial Production}

Industrial production figures bring information about the current state and short-term prospects of the economy and about the performance of industrial, as opposed to service, 
companies. One would expect the stock market, and perhaps the foreign exchange market, to react to this kind of news. In general, the interest rates and bond yields could also be affected if the information about industrial production was expected to have an impact on the central bank's monetary policy. In the Czech Republic though, one would not expect any strong interest rate reaction, since during the period under study, the central bank was viewed as paying little attention to the short term development of output. One should also note that the industrial results are released with almost two months' delay and that some information about industrial performance can be gained sooner by looking at the trade deficit figures (released with only approximately one month delay). Foreign trade helps predict industry performance because a substantial part of the Czech industrial production is exported.

Table 5: Overview of the Regression Results for Industrial Production

\begin{tabular}{|c|c|c|c|c|c|c|c|c|c|c|c|c|c|c|c|c|c|c|c|c|c|c|c|c|}
\hline & \multicolumn{2}{|c|}{$\begin{array}{l}\text { PRIB } \\
1 \mathrm{~W}\end{array}$} & \multicolumn{2}{|c|}{$\begin{array}{c}\text { PRIB } \\
1 \mathrm{M}\end{array}$} & \multicolumn{2}{|c|}{$\begin{array}{c}\text { PRIB } \\
6 \mathrm{M}\end{array}$} & \multicolumn{2}{|c|}{$\begin{array}{c}\text { PRIB } \\
1 \mathrm{Y}\end{array}$} & \multicolumn{2}{|c|}{$\begin{array}{l}\text { GOV } \\
\text { YLD }\end{array}$} & \multicolumn{2}{|c|}{$\begin{array}{c}\text { SWAP } \\
5 \mathrm{Y}\end{array}$} & \multicolumn{2}{|c|}{$\begin{array}{l}\text { SWAP } \\
10 Y\end{array}$} & \multicolumn{2}{|c|}{$\begin{array}{c}\text { FWD } \\
3 * 6\end{array}$} & \multicolumn{2}{|c|}{$\begin{array}{l}\text { FWD } \\
9 * 12\end{array}$} & \multicolumn{2}{|c|}{ USD } & \multicolumn{2}{|c|}{$\overline{D E M}$} & \multicolumn{2}{|c|}{ PX-50 } \\
\hline & $E x$ & $\mathrm{Sr}$ & $\mathrm{Ex}$ & $\mathrm{Sr}$ & $\overline{E x}$ & $\overline{\mathrm{Sr}}$ & $E x$ & $\overline{\mathrm{Sr}}$ & $\mathrm{Ex}$ & $\mathrm{Sr}$ & $E x$ & $\mathrm{Sr}$ & $\mathrm{Ex}$ & $\mathrm{Sr}$ & $\mathrm{Ex}$ & $\mathrm{Sr}$ & $E x$ & $\mathrm{Sr}$ & Ex & $\mathrm{Sr}$ & Ex & $\mathrm{Sr}$ & Ex & $\mathrm{Sr}$ \\
\hline T-2 & & & & & & & & & & & & & & & $*$ & & & & & & & & $*$ & \\
\hline T-1 & & & & & & & & & & & & & & + & & & $*$ & & $*$ & & & ++ & & \\
\hline $\mathbf{T}$ & & & & & & & $*$ & & & & $* *$ & & $* *$ & & & & & & & & & & & ** \\
\hline $\mathrm{T}+1$ & & & & & & & & & & & & & & & & & & & & & & & & \\
\hline $\mathrm{T}+2$ & & & & & & & & & & & & & & & & & & & & ++ & & & + & \\
\hline $\mathrm{T}+3$ & & & & & & & & & & & & & & & $* *$ & & & & + & $* *$ & & $* *$ & & \\
\hline $\mathrm{T}+4$ & & & & & & + & & & & & & + & & + & & & & & & & & ++ & & \\
\hline $\mathrm{T}+5$ & & & & + & & + & & + & & & & & & & $*$ & & & & & & & $*$ & & \\
\hline $\mathrm{T}+6$ & & & $* *$ & & $* *$ & & $*$ & & & & & & & & & & & & & & & & * & \\
\hline $\mathrm{T}+7$ & & & & & & & & & & & & & & & & & & & & $* *$ & & $* *$ & & \\
\hline $\mathrm{T}+8$ & & & & + & & + & & & $* *$ & & & $*$ & & & & & $*$ & & & & & & & \\
\hline
\end{tabular}

Note: Negative coefficients significant at the 10\% (*) level and $5 \%(* *)$ level. Positive coefficients significant at the 10\% (+) level and 5\% (++) level. Ex = expected, $\mathrm{Sr}=$ surprise. We report results through day T-2 because, in terms of this table, poll results are usually released in the afternoon of day T-3.

The results generally confirm expectations that interest rates react little to the releases. Longer rates, that is, swaps and the 1 year PRIBOR, might be considered exceptions. These rates decreased with higher industrial production on the day of the release $(\mathrm{T})$. There was also some reaction of the exchange rate, but different coefficient signs and delayed response make interpretation difficult. Contrary to expectations, neither does the stock market appear to significantly react to industrial production figures. The coefficient on day $\mathrm{T}$ (Surprise) is significant, but it is negative, which is virtually impossible to interpret-higher industry output would imply lower stock prices. Overall, it does not appear that industrial data would 
be important for the Czech financial markets. The test for structural break did not reveal any significant differences between the two time periods.

\subsection{Foreign Trade}

Foreign trade figures should be primarily of interest to the foreign exchange market and, to a lesser extent, to the stock market. One would expect that interest rates and yields would not be systematically affected by the trade figures.

Our estimates suggest that the foreign exchange market indeed reacts to trade deficit announcements with the exchange rate against the Deutsche Mark (Euro) exhibiting stronger reaction than the rate vis-a-vis the U.S. dollar. This is quite natural, since Germany is the main trading partner of the Czech Republic and the central bank primarily follows the exchange rate relative to the DEM (Euro). A majority of the significant coefficients are positive, which corresponds to the expectation that higher trade deficit should lead to depreciation of the currency. In case of the DEM, the positive coefficient on day $\mathrm{T}$ is corrected on day $\mathrm{T}+1$. It is also notable that both the DEM and USD appear to react to the expected part of the release (on day $\mathrm{T}$ ).

Table 6: Overview of the Regression Results for Foreign Trade Deficit

\begin{tabular}{|c|c|c|c|c|c|c|c|c|c|c|c|c|c|c|c|c|c|c|c|c|c|c|c|c|}
\hline & \multicolumn{2}{|c|}{$\begin{array}{c}\text { PRIB } \\
1 \mathrm{~W}\end{array}$} & \multicolumn{2}{|c|}{$\begin{array}{c}\text { PRIB } \\
1 \mathrm{M} \\
\end{array}$} & \multicolumn{2}{|c|}{$\begin{array}{c}\text { PRIB } \\
6 \mathrm{M}\end{array}$} & \multicolumn{2}{|c|}{$\begin{array}{c}\text { PRIB } \\
1 Y\end{array}$} & \multicolumn{2}{|c|}{$\begin{array}{l}\text { GOV } \\
\text { YLD }\end{array}$} & \multicolumn{2}{|c|}{$\begin{array}{c}\text { SWAP } \\
5 \mathrm{Y}\end{array}$} & \multicolumn{2}{|c|}{$\begin{array}{c}\text { SWAP } \\
10 Y\end{array}$} & \multicolumn{2}{|c|}{$\begin{array}{c}\text { FWD } \\
3 * 6 \\
\end{array}$} & \multicolumn{2}{|c|}{$\begin{array}{l}\text { FWD } \\
9 * 12 \\
\end{array}$} & \multicolumn{2}{|c|}{ USD } & \multicolumn{2}{|c|}{ DEM } & \multicolumn{2}{|c|}{ PX-50 } \\
\hline & $E x$ & $\mathrm{Sr}$ & $E x$ & $\mathrm{Sr}$ & Ex & $\mathrm{Sr}$ & Ex & $\mathrm{Sr}$ & Ex & $\mathrm{Sr}$ & Ex & $\mathrm{Sr}$ & Ex & $\mathrm{Sr}$ & $E x$ & $\mathrm{Sr}$ & Ex & $\mathrm{Sr}$ & Ex & $\mathrm{Sr}$ & Ex & $\mathrm{Sr}$ & Ex & $\mathrm{Sr}$ \\
\hline T-5 & & & & & & & & & & & & & & & & & & & & & & & & \\
\hline T-4 & & & & & & ** & & & & ** & & & & & $* *$ & $* *$ & $*$ & $* *$ & & & & & & \\
\hline T-3 & & & $* *$ & $*$ & ** & $*$ & $* *$ & $*$ & $*$ & & ** & & & & $* *$ & & $*$ & & & & $* *$ & & & \\
\hline T-2 & & & $* *$ & & ** & & $* *$ & & & & & & $*$ & & & & & & & & & ++ & & \\
\hline T-1 & & & & & & & & & & & & ++ & $*$ & ++ & & & & & & & & & & $*$ \\
\hline $\mathbf{T}$ & & & & & & ++ & & ++ & & & & & & + & & & & + & ++ & & ++ & + & & \\
\hline $\mathrm{T}+1$ & & & & & & & & & & $*$ & $*$ & & & & & & & & & & $* *$ & $* *$ & & \\
\hline $\mathrm{T}+2$ & $*$ & & & & & & & & & & & & & & & & & & & & & & + & \\
\hline $\mathrm{T}+3$ & & + & & ++ & & & & & & + & & & & & + & & & & & & & & & \\
\hline $\mathrm{T}+4$ & & & & & & + & & & & ++ & & ++ & & ++ & & & & & & & & & & \\
\hline $\mathrm{T}+5$ & & & & + & & + & & + & & ++ & & & & & & & & + & & ++ & & & & \\
\hline $\mathrm{T}+6$ & & & & & & & & & & & & & $*$ & & $* *$ & & * & & & ++ & & ++ & & \\
\hline $\mathrm{T}+7$ & $*$ & & $*$ & & $*$ & & & & & & & & & & & & & & & $*$ & & $* *$ & & \\
\hline $\mathrm{T}+8$ & & & & & & & & & & & & & & & & & & & & $*$ & & & & \\
\hline
\end{tabular}
significant at the 10\% (+) level and 5\% (++) level. Ex = expected, Sr $=$ surprise. 
Inter-bank interest rates did not exhibit any major reaction to the trade data. There is some reaction on the release day $(\mathrm{T})-6$ months and 1 year PRIBOR, 10 year swap and forward $9 * 12$ reacted to the surprise-but otherwise there is not much to comment on. Some delayed adjustment is seen in the case of the government bond. The coefficients are mostly positive, which could be explained by a fear that growing external imbalance will induce monetary tightening. As for the stock market, we found that only one coefficient after the release was significant (day $\mathrm{T}+2$ ). It is positive, which implies that wider deficit leads to higher stock prices. Testing for structural break did not reveal any structural break within the time period under study. 


\section{Conclusions}

In the presented paper, we investigated the financial market efficiency in an economy in transition from the viewpoint of its reaction to new information. The focus was on the response of the Czech financial market to macroeconomic releases. We examined the reaction of interest rates, the government bond yield, the stock market index and foreign exchange rates to the announcements of consumer and producer prices, industrial production and foreign trade figures. Out of these, consumer prices appear to be the most important macroeconomic release in terms of market response and, at the same time, interest rates appear to be most responsive to the releases. Our results suggest that Czech interest rates react in line with expectations derived from theoretical models - higher than expected inflation leads to an increase in interest rates.

The main conclusion of the current paper, however, is that the market does not react efficiently, and this holds for virtually all of its segments. Firstly, it reacts to the expected component of the releases. Secondly, the releases often retain their explanatory power for daily changes of financial variables for several days after the announcement. We also found signs of overreaction that is subsequently corrected. Only in the case of the consumer price index we were able to find evidence which can be interpreted as suggesting that the market becomes more efficient over time.

The described lack of efficiency is surprising because both the money market and the foreign exchange markets appear to be rather developed and liquid. Matalík et al. (1999) report that the average daily volume on the inter-bank money market was approximately $26-$ 30 billion CZK (almost 0.9 billion USD) in 1999. On the foreign exchange market, the Czech National Bank reports daily trading volumes of several billion USD, which compares favorably even with some developed markets. In the most recent report, which compares 
trading volumes in foreign exchange markets, the Bank for International Settlements informs that Portugal and Finland had daily foreign exchange turnover of 4.4 bn USD and 4.2 bn USD in April 1998, respectively. This turnover amounted to 5.0 bn USD in case of the Czech Republic. $^{20}$

The fact that the market response takes several days appears to be unusual, but most puzzling is the fact that the market reacts to the expected part of the release. This directly contradicts the conclusions of most developed-market studies. In that environment, the empirical results imply that asset prices respond only to the unexpected part of the announcement as predicted by the efficient market hypothesis. In this regard, an argument might be made that the survey data used do not represent market expectations. The presented evidence, however, suggests that the poll forecast is close to being rational. More importantly though, such a claim would not, in fact, contradict our conclusion that the market is inefficient. No matter whether the existing poll results represent market expectations or not, there simply exists widely distributed information, the poll, which is not incorporated into prices, because it is capable of explaining market returns after macroeconomic release is announced.

\footnotetext{
${ }^{20}$ See the Triennial Central Bank Survey of Foreign Exchange and Derivatives Market Activity.
} 


\section{References}

Aggarwal, Raj, Sunil Mohanty, and Frank Song. 1995. "Are Survey Forecasts of Macroeconomic Variables Rational?” Journal of Business. 68 (1), pages 99-119.

Almeida, Alvaro, Charles Goodhart, and Richard Payne. 1998. "The Effects of Macroeconomic News on High Frequency Exchange Rate Behavior". Journal of Financial and Quantitative Analysis. 33 (3), September 1998, pages 383-408.

Aminud, Yakov. 1996. "Unexpected Inflation and Stock Returns Revisited-Evidence from Israel”. Journal of Money, Credit and Banking. 28 (1), February 1996, pages 22-33.

Deaves, Richard. "Money Supply Announcements and Market Reaction in an Open Economy”. Journal of Money, Credit and Banking. 22(2), May 1990, pages 154-164.

Ederington, Louis H. and Jae Ha Lee. 1995. "The Short Run Dynamics of the Price Adjustment to New Information”. Journal of Financial and Quantitative Analysis. 30 (1), March 1995, pages 117-134.

Fleming, Michael J. and Eli M. Remolona. 1999. "The Term Structure of Announcement Effects”. BIS Working Paper No. 71. June 1999.

Hoffman, Dennis L. and Don E. Schlagenhauf. 1985. "The Impact of News and Alternative Theories of Exchange Rate Determination". Journal of Money, Credit and Banking. 17 (3), August 1985, pages 328-346.

Inflation Report October 1999. 1999. Prague: Czech National Bank.

Matalík, Ivan, Ivana Matalíková, Štěpán Radkovský, and Jan Syrovátka. 1999. “Možnosti měření inflačních očekávání na českém finančním trhu (Measurement of Inflation Expectations at the Czech Financial Market)". Finance a úvěr. 49 (8), August 1999, pages 449-465.

Podpiera, Richard. 2000. "Efektivnost českého finančního trhu ve světle snižování úrokových sazeb (Czech Financial Market Efficiency in Light of Recent Interest Rate Cuts)". Finance a úvěr. 50 (5), May 2000, pages 270-282.

Sadeghi, Mehdi. 1992. "Stock Market Response to Unexpected Macroeconomic News: The Australian Evidence”. IMF Working Paper. 92/61, August 1992.

Smirlock, Michael. 1986. "Inflation Announcements and Financial Market Reaction: Evidence from the Long-Term Bond Market". Review of Economics and Statistics. 68(2), May 1986, pages 329-33.

Triennial Central Bank Survey of Foreign Exchange and Derivatives Market Activity 1998. 1999. Basel: Bank for International Settlements.

Urich, Thomas and Paul Wachtel. 1981. "Market Response to the Weekly Money Supply Announcements in the 1970's". Journal of Finance. 36, December 1981, pages 1063-1072. 


\section{Appendix}

T-statistics are reported below the coefficient estimates. Coefficients at the Expected and Surprise variables that are statistically significant at the $10 \%$ level are marked by $*$, while the $5 \%$ significance level is marked as $* *$. Please note that the different number of observations is caused by missing data, mostly due to holidays. Only a very restricted sample of the results is presented. The full set of results is available upon request from the author.

\section{M PRIBOR response to CPI announcement}

\begin{tabular}{|r|r|r|r|r|r|r|r|}
\hline & Expected & Surprise & Repo & Weekend & Dummy & NOB & R-squared \\
\hline Day T-1 (coefficient) & 0.01 & 0.00 & -- & -- & -0.07 & 29 & $1 \%$ \\
\hline t-statistics & 0.30 & 0.00 & -- & -- & -1.12 & & \\
\hline Day T (coefficient) & $\mathbf{- 0 . 0 1}$ & $\mathbf{0 . 1 0} * *$ & $\mathbf{0 . 4 5} * *$ & -- & $\mathbf{0 . 0 2}$ & $\mathbf{3 0}$ & $\mathbf{4 7 \%}$ \\
\hline t-statistics & $\mathbf{- 0 . 4 7}$ & $\mathbf{2 . 7 6}$ & $\mathbf{1 3 . 9 9}$ & -- & $\mathbf{0 . 3 2}$ & & \\
\hline Day T+1 (coefficient) & $0.02^{*}$ & 0.07 & $0.39^{* *}$ & -0.03 & $-0.27^{* *}$ & 30 & $89 \%$ \\
\hline t-statistics & 1.84 & 1.40 & 74.80 & -1.36 & -3.54 & & \\
\hline Day T+2 (coefficient) & $0.02^{* *}$ & $-0.10^{*}$ & $0.06^{* *}$ & -0.03 & -0.06 & 30 & $29 \%$ \\
\hline t-statistics & 3.33 & -2.01 & 7.81 & -1.23 & -0.88 & & \\
\hline Day T+3 (coefficient) & 0.04 & 0.02 & -- & -0.01 & -0.11 & 29 & $14 \%$ \\
\hline t-statistics & 1.57 & 0.36 & -- & -0.62 & -1.09 & & \\
\hline Day T+4 (coefficient) & $0.14^{* *}$ & $-0.25^{* *}$ & $0.74^{* *}$ & $-0.09^{* *}$ & 0.02 & 29 & $66 \%$ \\
\hline t-statistics & 5.13 & -2.81 & 11.80 & -3.30 & 0.28 & & \\
\hline Day T+5 (coefficient) & $-0.10^{* *}$ & $0.14^{*}$ & $0.92^{* *}$ & -- & 0.09 & 30 & $73 \%$ \\
\hline t-statistics & -2.19 & 1.86 & 47.85 & -- & 0.64 & & \\
\hline Day T+6 (coefficient) & -0.05 & 0.11 & $-0.09^{* *}$ & -- & 0.01 & 30 & $1 \%$ \\
\hline t-statistics & -1.40 & 1.53 & -4.34 & -- & 0.11 & & \\
\hline Day T+7 (coefficient) & -0.01 & 0.10 & $0.28^{* *}$ & -- & -0.17 & 30 & $3 \%$ \\
\hline t-statistics & -0.98 & 0.97 & 5.87 & -- & -1.24 & & \\
\hline Day T+8 (coefficient) & -0.01 & -0.13 & -- & -- & 0.16 & 30 & $4 \%$ \\
\hline t-statistics & -0.83 & -0.72 & -- & -- & 0.69 & & \\
\hline
\end{tabular}

\section{Y SWAP response to CPI announcement}

\begin{tabular}{|r|r|r|r|r|r|r|r|}
\hline & Expected & Surprise & Repo & Weekend & Dummy & NOB & R-squared \\
\hline Day T-1 (coefficient) & $0.07 *$ & 0.02 & - & - & -0.22 & 29 & $35 \%$ \\
\hline t-statistics & 1.81 & 0.23 & -- & -- & -1.39 & & \\
\hline Day T (coefficient) & $\mathbf{- 0 . 0 1}$ & $\mathbf{0 . 1 9}$ & $\mathbf{0 . 0 0}$ & -- & $\mathbf{- 0 . 0 6}$ & $\mathbf{2 9}$ & $\mathbf{2 2 \%}$ \\
\hline t-statistics & $\mathbf{- 0 . 7 2}$ & $\mathbf{1 . 7 6}$ & $\mathbf{- 0 . 0 4}$ & - & $\mathbf{- 0 . 3 6}$ & & \\
\hline Day T+1 (coefficient) & $0.09^{* *}$ & -0.04 & $0.04 * *$ & $-0.06^{* *}$ & $-0.34 *$ & 30 & $43 \%$ \\
\hline t-statistics & 2.35 & -0.50 & 2.52 & -2.26 & -2.08 & & \\
\hline Day T+2 (coefficient) & 0.02 & -0.08 & $1.03^{* *}$ & -0.01 & 0.00 & 28 & $51 \%$ \\
\hline t-statistics & 1.46 & -0.94 & 57.72 & -0.33 & 0.00 & & \\
\hline Day T+3 (coefficient) & -0.04 & 0.01 & -- & -0.02 & 0.00 & 27 & $11 \%$ \\
\hline t-statistics & -1.37 & 0.08 & -- & -0.71 & 0.00 & & \\
\hline Day T+4 (coefficient) & $0.02^{* *}$ & 0.10 & 0.03 & -0.04 & 0.00 & 29 & $31 \%$ \\
\hline t-statistics & 2.91 & 1.07 & 0.74 & -1.37 & 0.03 & & \\
\hline Day T+5 (coefficient) & 0.03 & 0.05 & 0.01 & -- & 0.01 & 28 & $9 \%$ \\
\hline t-statistics & 1.12 & 0.82 & 0.91 & -- & 0.10 & & \\
\hline Day T+6 (coefficient) & $-0.05 * *$ & 0.08 & $0.47 * *$ & -- & -0.02 & 27 & $29 \%$ \\
\hline t-statistics & -2.21 & 0.94 & 33.28 & -- & -0.12 & & \\
\hline Day T+7 (coefficient) & 0.00 & 0.09 & -0.03 & -- & -0.17 & 29 & $1 \%$ \\
\hline t-statistics & 0.13 & 0.76 & -0.44 & -- & -1.05 & & \\
\hline Day T+8 (coefficient) & 0.02 & 0.12 & -- & -- & -0.19 & 29 & $1 \%$ \\
\hline t-statistics & 0.19 & 1.02 & -- & -- & -1.04 & & \\
\hline
\end{tabular}


CZK/DEM exchange rate response to CPI announcement

\begin{tabular}{|r|r|r|r|r|r|r|r|}
\hline & Expected & Surprise & Repo & Weekend & Dummy & NOB & R-squared \\
\hline Day T-1 (coefficient) & 0.00 & 0.00 & -- & -- & -0.02 & 29 & $19 \%$ \\
\hline t-statistics & 0.87 & -0.21 & -- & -- & -1.50 & & \\
\hline Day T (coefficient) & $\mathbf{0 . 0 0}$ & $\mathbf{- 0 . 0 1}$ & $\mathbf{0 . 0 0}$ & -- & $\mathbf{0 . 0 1}$ & $\mathbf{2 9}$ & $\mathbf{4 \%}$ \\
\hline t-statistics & $\mathbf{0 . 4 0}$ & $-\mathbf{- 0 . 7 1}$ & $\mathbf{0 . 3 2}$ & - & $\mathbf{0 . 5 3}$ & & \\
\hline Day T+1 (coefficient) & $0.01^{*}$ & $-0.02^{*}$ & $0.01^{* *}$ & 0.00 & 0.00 & 29 & $28 \%$ \\
\hline t-statistics & 1.94 & -2.05 & 3.59 & -0.55 & 0.06 & & \\
\hline Day T+2 (coefficient) & 0.00 & 0.00 & $0.02^{* *}$ & 0.00 & -0.01 & 28 & $12 \%$ \\
\hline t-statistics & 0.17 & 0.09 & 4.94 & -0.70 & -0.37 & & \\
\hline Day T+3 (coefficient) & 0.00 & -0.01 & -- & 0.00 & 0.01 & 28 & $12 \%$ \\
\hline t-statistics & 0.30 & -1.04 & -- & -0.51 & 1.20 & & \\
\hline Day T+4 (coefficient) & $0.005^{* *}$ & 0.00 & 0.00 & 0.00 & -0.01 & 29 & $18 \%$ \\
\hline t-statistics & 3.47 & -0.31 & -0.35 & -1.42 & -1.01 & & \\
\hline Day T+5 (coefficient) & $-0.003^{* *}$ & -0.01 & 0.00 & -- & $0.02 * *$ & 29 & $16 \%$ \\
\hline t-statistics & -2.59 & -1.55 & 1.62 & -- & 3.56 & & \\
\hline Day T+6 (coefficient) & 0.00 & 0.00 & $0.003^{* *}$ & -- & 0.00 & 29 & $9 \%$ \\
\hline t-statistics & -0.49 & -0.63 & 5.34 & -- & -0.32 & & \\
\hline Day T+7 (coefficient) & 0.00 & 0.01 & $0.04^{* *}$ & -- & $-0.01^{* *}$ & 29 & $22 \%$ \\
\hline t-statistics & -0.06 & 1.62 & 14.14 & -- & -2.24 & & \\
\hline Day T+8 (coefficient) & 0.00 & -0.01 & -- & -- & 0.01 & 29 & $16 \%$ \\
\hline t-statistics & 1.47 & -0.96 & -- & -- & 0.89 & & \\
\hline
\end{tabular}

\section{Y PRIBOR response to PPI announcement}

\begin{tabular}{|c|c|c|c|c|c|c|}
\hline & Expected & Surprise & Repo & Weekend & NOB & R-squared \\
\hline Day T-4 (coefficient) & 0.01 & 0.04 & -- & -- & 29 & $4 \%$ \\
\hline t-statistics & 0.55 & 0.88 & -- & -- & & \\
\hline Day T-3 (coefficient) & 0.02 & 0.02 & $0.48^{* *}$ & -- & 30 & $9 \%$ \\
\hline t-statistics & 0.55 & 0.36 & 17.59 & -- & & \\
\hline Day T-2 (coefficient) & -0.01 & -0.01 & $0.10^{* *}$ & - & 30 & $7 \%$ \\
\hline t-statistics & -0.33 & -0.10 & 7.17 & -- & & \\
\hline Day T-1 (coefficient) & -0.01 & -0.04 & $0.27 * *$ & -- & 29 & $18 \%$ \\
\hline t-statistics & -0.42 & -0.75 & 9.86 & -- & & \\
\hline Day $T$ (coefficient) & 0.03 & $0.04 *$ & -- & - & 29 & $4 \%$ \\
\hline t-statistics & 1.20 & 1.73 & -- & -- & & \\
\hline Day T+1 (coefficient) & $0.08 * *$ & $0.11 *$ & $0.41 * *$ & $-0.09 * *$ & 30 & $41 \%$ \\
\hline t-statistics & 2.25 & 1.84 & 4.67 & -3.66 & & \\
\hline Day T+2 (coefficient) & 0.01 & $0.06 *$ & $0.41 * *$ & -0.01 & 30 & $31 \%$ \\
\hline t-statistics & 0.22 & 2.05 & 7.33 & -0.42 & & \\
\hline Day T+3 (coefficient) & 0.05 & $0.05^{*}$ & $0.13^{* *}$ & $-0.06^{* *}$ & 30 & $6 \%$ \\
\hline t-statistics & 1.22 & 1.76 & 10.79 & -2.30 & & \\
\hline Day T+4 (coefficient) & 0.07 & 0.05 & 0.13 & $-0.08 * *$ & 30 & $7 \%$ \\
\hline t-statistics & 1.09 & 1.06 & 1.38 & -2.11 & & \\
\hline Day T+5 (coefficient) & 0.00 & -0.01 & -- & -- & 30 & $0 \%$ \\
\hline t-statistics & -0.25 & -0.13 & -- & -- & & \\
\hline Day T+6 (coefficient) & -0.02 & 0.05 & $-0.43^{* *}$ & -- & 29 & $3 \%$ \\
\hline t-statistics & -0.51 & 1.03 & -3.18 & -- & & \\
\hline Day T+7 (coefficient) & 0.02 & 0.02 & -- & -- & 28 & $1 \%$ \\
\hline t-statistics & 0.97 & 0.34 & -- & -- & & \\
\hline Day T+8 (coefficient) & 0.00 & 0.00 & $0.07^{* *}$ & -- & 29 & $2 \%$ \\
\hline t-statistics & \begin{tabular}{|c|}
-0.12 \\
\end{tabular} & -0.11 & 5.82 & -- & & \\
\hline
\end{tabular}


CZK/DEM exchange rate response to industrial production announcement

\begin{tabular}{|c|c|c|c|c|c|c|}
\hline & Expected & Surprise & Repo & Weekend & NOB & R-squared \\
\hline Day T-2 (coefficient) & 0.00 & 0.00 & -- & -- & 29 & $2 \%$ \\
\hline t-statistics & -1.17 & -0.12 & -- & -- & & \\
\hline Day T-1 (coefficient) & 0.00 & $0.001 * *$ & $0.005 * *$ & -- & 29 & $11 \%$ \\
\hline t-statistics & 0.86 & 2.41 & 4.09 & -- & & \\
\hline Day $T$ (coefficient) & 0.00 & 0.00 & 0.01 & -- & 29 & $7 \%$ \\
\hline t-statistics & 0.70 & -1.35 & 0.79 & -- & & \\
\hline Day $\mathrm{T}+1$ (coefficient) & 0.00 & 0.00 & 0.01 & 0.00 & 28 & $5 \%$ \\
\hline t-statistics & -0.12 & 0.72 & 0.94 & -0.73 & & \\
\hline Day $\mathrm{T}+2$ (coefficient) & 0.00 & 0.00 & -- & 0.00 & 28 & $2 \%$ \\
\hline t-statistics & 0.09 & -0.02 & -- & 0.08 & & \\
\hline Day $\mathrm{T}+3$ (coefficient) & 0.00 & $-0.001 * *$ & -- & 0.00 & 29 & $9 \%$ \\
\hline t-statistics & 0.90 & -2.41 & -- & -0.24 & & \\
\hline Day $\mathrm{T}+4$ (coefficient) & 0.00 & $0.001 * *$ & $-0.01 * *$ & $0.004 * *$ & 29 & $37 \%$ \\
\hline t-statistics & -0.30 & 2.69 & -4.38 & -5.47 & & \\
\hline Day $\mathrm{T}+5$ (coefficient) & 0.00 & $-0.001 *$ & 0.00 & -- & 29 & $13 \%$ \\
\hline t-statistics & -0.52 & -1.77 & 1.58 & -- & & \\
\hline Day $\mathrm{T}+6$ (coefficient) & 0.00 & 0.00 & $0.02 * *$ & -- & 29 & $11 \%$ \\
\hline t-statistics & -1.13 & -0.55 & 6.36 & -- & & \\
\hline Day $\mathrm{T}+7$ (coefficient) & 0.00 & $-0.001 * *$ & -- & -- & 29 & $13 \%$ \\
\hline t-statistics & 1.49 & -2.58 & -- & -- & & \\
\hline Day $\mathrm{T}+8$ (coefficient) & 0.00 & 0.00 & -- & -- & 29 & $4 \%$ \\
\hline t-statistics & -0.92 & -0.41 & -- & -- & & \\
\hline
\end{tabular}


CZK/DEM exchange rate response to trade deficit announcement

\begin{tabular}{|c|c|c|c|c|c|c|}
\hline & Expected & Surprise & Repo & Weekend & NOB & R-squared \\
\hline Day T-5 (coefficient) & 0.00 & 0.00 & $-0.01 *$ & -- & 30 & $7 \%$ \\
\hline t-statistics & -0.11 & -0.99 & -1.83 & -- & & \\
\hline Day T-4 (coefficient) & 0.00 & 0.00 & 0.00 & -- & 30 & $11 \%$ \\
\hline t-statistics & -0.90 & -1.36 & -1.43 & -- & & \\
\hline Day T-3 (coefficient) & $-0.0003 * *$ & 0.00 & -0.01 & -- & 30 & $4 \%$ \\
\hline t-statistics & -2.12 & 1.35 & -1.23 & -- & & \\
\hline Day T-2 (coefficient) & 0.00 & $0.001 * *$ & $0.06 * *$ & -- & 30 & $37 \%$ \\
\hline t-statistics & 0.96 & 3.81 & 11.64 & -- & & \\
\hline Day T-1 (coefficient) & 0.00 & 0.00 & -- & -- & 30 & $4 \%$ \\
\hline t-statistics & -0.04 & 1.03 & -- & -- & & \\
\hline Day $T$ (coefficient) & $0.0005 * *$ & $0.0005 *$ & 0.01 & -- & 30 & $12 \%$ \\
\hline t-statistics & 3.07 & 1.64 & 1.45 & -- & & \\
\hline Day $\mathrm{T}+1$ (coefficient) & $-0.001 * *$ & $-0.001 * *$ & -- & 0.00 & 30 & $31 \%$ \\
\hline t-statistics & -3.01 & -3.27 & -- & 0.98 & & \\
\hline Day $\mathrm{T}+2$ (coefficient) & 0.00 & 0.00 & 0.00 & 0.00 & 30 & $4 \%$ \\
\hline t-statistics & -0.07 & 0.92 & 0.24 & 0.05 & & \\
\hline Day $\mathrm{T}+3$ (coefficient) & 0.00 & 0.00 & -- & 0.00 & 30 & $5 \%$ \\
\hline t-statistics & -0.17 & 1.41 & -- & 0.17 & & \\
\hline Day $\mathrm{T}+4$ (coefficient) & 0.00 & 0.00 & $0.01 *$ & 0.00 & 28 & $16 \%$ \\
\hline t-statistics & 0.04 & -0.87 & 1.77 & 0.68 & & \\
\hline Day $\mathrm{T}+5$ (coefficient) & 0.00 & 0.00 & 0.00 & -- & 27 & $14 \%$ \\
\hline t-statistics & -0.52 & 1.51 & -0.83 & -- & & \\
\hline Day $\mathrm{T}+6$ (coefficient) & 0.00 & $0.001 * *$ & $0.01 * *$ & -- & 29 & $48 \%$ \\
\hline t-statistics & -0.60 & 2.43 & 20.08 & -- & & \\
\hline Day T+7 (coefficient) & 0.00 & $-0.001 * *$ & 0.00 & -- & 29 & $15 \%$ \\
\hline t-statistics & -0.83 & -2.54 & -0.11 & -- & & \\
\hline Day $\mathrm{T}+8$ (coefficient) & 0.00 & 0.00 & 0.00 & -- & 30 & $4 \%$ \\
\hline t-statistics & -1.25 & 0.07 & 0.10 & -- & & \\
\hline
\end{tabular}

